\title{
The Current Railway Development and Its Influencing Factors in Ghana
}

\author{
Larsey Naphtali Akwetteh1, Chaoyi Xu' ${ }^{1}$, Monica Dita Pravita Widya Putri', \\ Larsey Nathanael Okoe ${ }^{2}$ \\ ${ }^{1}$ School of Economics and Management, Anhui University of Science and Technology, Huainan, China \\ ${ }^{2}$ School of Engineering, Huzhou University, Huzhou, China \\ Email: nlarsey.nl@gmail.com,3910379@qq.com, monicadpwp@gmail.com,natlarsey1@gmail.com
}

How to cite this paper: Akwetteh, L. N., Xu, C. Y., Putri, M. D. P. W., \& Okoe, L. N. (2021). The Current Railway Development and Its Influencing Factors in Ghana. Open Journal of Social Sciences, 9, 228-244. https://doi.org/10.4236/jss.2021.93015

Received: February 7, 2021

Accepted: March 19, 2021

Published: March 22, 2021

Copyright ( 2021 by author(s) and Scientific Research Publishing Inc. This work is licensed under the Creative Commons Attribution International License (CC BY 4.0).

http://creativecommons.org/licenses/by/4.0/ (c) (i) Open Access

\begin{abstract}
For a number of years, the Ghana Railway system and infrastructure have been unattractively inactive and have deprived the nation and economy of its development rate and living expenses substantially. Speed, space, weight, distance, expense and time are expedient with regards to a developing economy. Consider the gain if all these are catered for at least to an extent in the railway sector. Freight movement and passenger transport on a high rate could benefit the economy a great deal minimizing a lot of expense, accidents, traffics etc. and also lead dramatically towards increased commodity production, trade boost and people development. With the recent plans by the Government on the trans-ECOWAS railway link and job creation, investment boundaries will be open to resource extraction and improved agricultural commerce. This paper primarily reflects the major drive towards the Ghana Railway Development. Certain influencing factors carefully searched out are outlined with a view at its high potential as a rail recovery cornerstone.
\end{abstract}

\section{Keywords}

Ghana, Railway, Development, Rehabilitations, Influencing Factors

\section{Introduction}

Between 1901 and 1923, railway lines were built connecting the coast and mining areas. This someway somehow exposed great expanses of tropical forest to cocoa cultivation, announcing Ghana as the world's largest producer. Many migrants came to producing areas and the economic surplus sped up urbanization. There has been a massive transformation with regards to the economic geography of Ghana since the Early Railway constructions. There have been more devel- 
opments in railway districts since the decline in rail transportations in recent times.

\subsection{Ghana and Her Railway Profile}

With Ghana becoming the first sub-Saharan African country to be independent from the United Kingdom in 1957, it was created as a parliamentary democracy with alternating military and civilian governments following up. Ghana is still acclaimed one of the best and thriving democratic country in Africa as well as being the most preferred destination for investment, hence, the gateway to West Africa. Ghana is an active member of the United Nations (UN), African Union (AU), African Caribbean, Pacific Group of States (ACP), World Trade Organizations (WTO), Economic Community of West African States (ECOWAS) and favors International and regional political and economic co-operation. Ghana's major source of foreign exchange is gold and cocoa exports as well as individual transmittals. Ghana provides a stable environment for investments ensuring the repatriation of capital and fair treatment of all investors regarding fiscal incentives (www.gfzb.gov.gh, 2020).

Ghana which was by then called Gold Coast had Railways as a wing of her Civil Service. Gradually, Ghana Railway Company Limited (GRCL) was created in March 2001 to provide the Railway operational services and in January 2009, Ghana Railway Development Authority (GRDA) was also created in order to also provide the requisite infrastructure in a bid to resuscitate the Railway Industry and facilitate the participation of private equity or sovereign wealth funds in the funding, growth and operation of the Railway network (www.grda.gov.gh, 2018). In January 2017, the Ministry of Transport under which the Railway sector operated, and the Ministry of Railways Development (MORD) was birthed to concentrate entirely on the complete revamp of the railway system with GRCL and GRDA under her.

\subsection{The Railway Conception}

In 1873, a railway proposal was made to connect Cape Coast to Kumasi through Prasu for war purposes. The British who was by then Ghana's colonial master wanted a fast way to send people to fight the Ashanti. A second proposal was made as the first did not work and this time with the goal of maximizing trade. It was very urgent to establish military domain and better the people's civilization. The project was to build a Saltpond-Oda-Kumasi railway but was set aside because of high budgets influenced by political instability and available funds. (Andoh, 2018). Dickson et al., reported that trade suffered constraints due to transport expenses that had gone skyrockets. The Southern region of Ghana as at the time had thick forests with only the inhabitants knowing the actual pathways. During those years between 1893 and 1899, several projects were planned on being executed but most failed due to expenses and preference. Eventually, there was a fortunate line from Sekondi reaching Tarkwa and Obuasi later extending to Kumasi. Other lines did not keep long in being built as Cocoa and 
Diamond production was to be taken advantage of Jedwab \& Moradi (2011b). The main factors that influenced the start of the inevitable Railway development were the purposes of mining, military control and the export of sultry products (Jedwab and Moradi, 2011a).

\subsection{Reviving the Rail System}

With about $97 \mathrm{~km}$ of railway lines in Ghana, only $64 \mathrm{~km}$ and $61 \mathrm{~km}$ of the Eastern line and Western line respectively were used due to exiguous pecuniary for physical and organizational structures and facilities. Ghana Railway Development Authority (2014) explained that freightage had reduced drastically from 1.8 million tons to about 154 thousand tons and rose a little after 2009. It finally got suspended due to rehabilitative, extension and burgeoning reasons. The railway network had been neglected over the years and because of deprived maintenance the rolling stock has to be replaced as well. Recently, there has been a salient look at the Railway development and its system, and a lot of advancement is being made towards a well-developed railway network.

The Western, Eastern and Central lines are the existing lines with current transversal link expansions and branch lines under rehabilitation. The railway previously served only the south since Accra is the capital until the mineral export traffic to the ports in Takoradi and Tema. The Western and Eastern lines served transportation mainly from Takoradi to Kumasi as well as Accra to Kumasi with Kumasi facing Tamale towards Paga. This has been clearly illustrated in Figure 1 below.

Figure 2 and Figure 3 shows the current Ghana Railway network diagram, the existing network and the expanding rail network. All six phases are inclusive with the priority phases (two, three, and five) undergoing rehabilitation.

Table 1 describes the six phases of railway line creation in Ghana commencing from rehabilitation of existing line to expansion of railway line to other regions in the country such as the Western region. Phase 2 is a standard gauge track conversion doubling the Phase 1 rehabilitated lines. It is a central spine

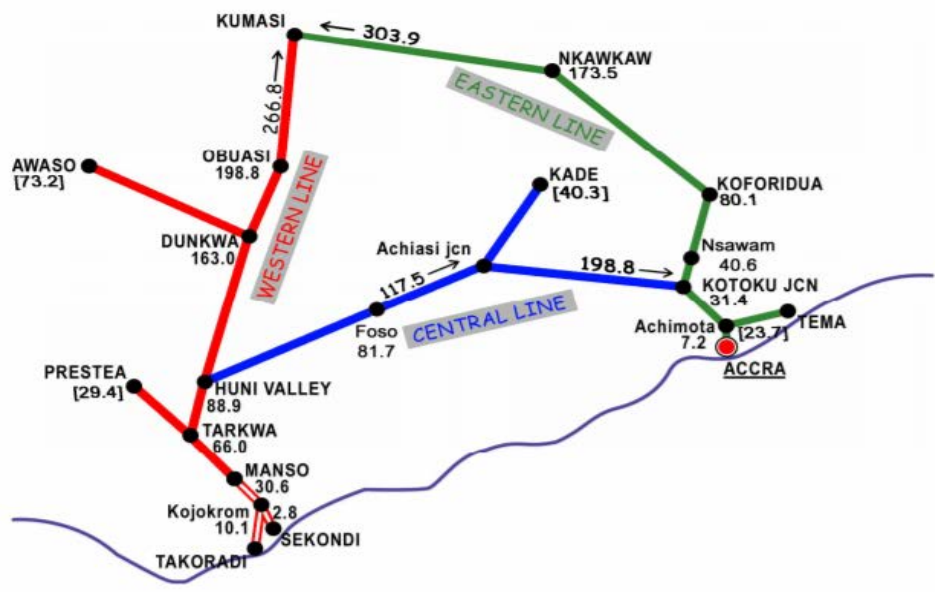

Figure 1. Ghana railway lines. Source: Ghana Railway Development Authority (2013). 


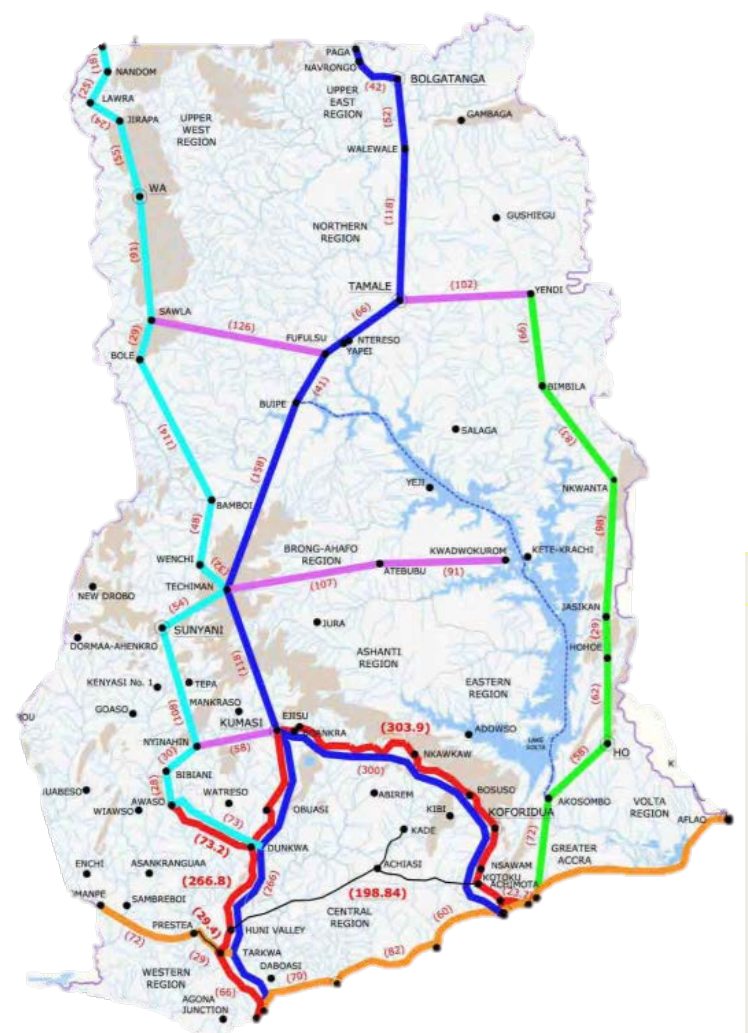

Figure 2. Rail line phases.

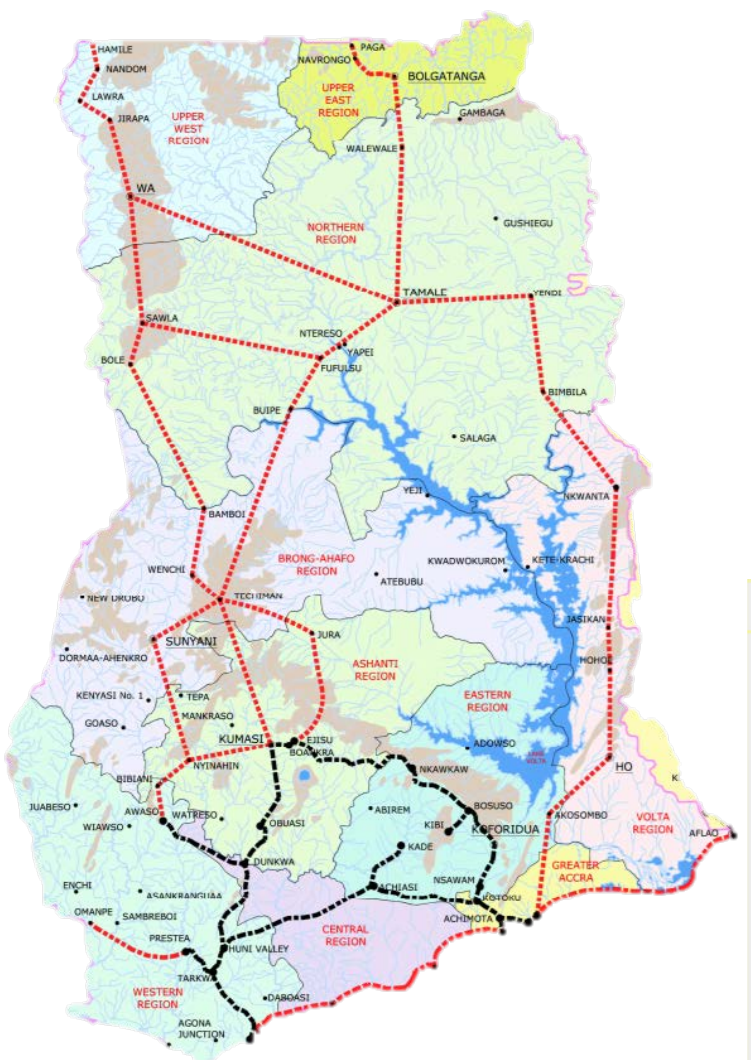

\section{LEGEND}

INTERNATIONAL BOUNDARIES REGIONAL BOUNDARIES

- national capital cities

- regional capital cities

- other cities RIVER

LAKE

.. EXISTING RAILWAY

MINISTRY PROPOSAL EXPANDING RAIL NETWORK

\section{LEGEND}

INTERNATIONAL BOUNDARIES REGIONAL BOUNDARIES

- national capital cities

- regional capital cities

- other cities RIVER

LAKE

... EXISTING RAILWAY

" MINISTRY PROPOSAL EXPANDING RAIL NETWORK

Figure 3. Existing and expansion rail line. 
Table 1. Phases of railway line creation.

\begin{tabular}{|c|c|}
\hline \multirow{2}{*}{ PHASE 1} & Rehabilitation of Existing lines, Narrow gauge \\
\hline & 1W Western Line $\quad$ 1E Eastern Line \\
\hline \multirow{2}{*}{ PHASE 2} & Central Spine Expansion, New Standard gauge \\
\hline & 2W Takoradi-Kumasi $\quad$ 2E Accra-Kumasi 2C Kumasi-Paga \\
\hline \multirow{3}{*}{ PHASE 3} & Transversal Expansion, New Standard gauge \\
\hline & 3.1 Tamale-Yendi $\quad 3.2$ Fufulsu-Sawla \\
\hline & 3.3 Techiman-Kwadwokurom $\quad 3.4$ Nyinahin-Kumasi \\
\hline PHASE 4 & $\begin{array}{l}\text { Trans Ecowas Expansion, New Standard gauge } \\
\text { Aflao-Accra-Takoradi-Omanpe }\end{array}$ \\
\hline PHASE 5 & $\begin{array}{l}\text { Western Expansion, New Standard gauge } \\
\text { Dunkwa-Awaso-Hamile }\end{array}$ \\
\hline PHASE 6 & $\begin{array}{l}\text { Eastern Expansion, New Standard gauge } \\
\text { Tema-Yendi }\end{array}$ \\
\hline
\end{tabular}

Source: Ghana Railway Development Authority (2013).

expansion (connects the Western and Eastern lines). Phase 3 is a transversal link expansion with standard gauge single tracks and Phase 5 is a standard gauge western line expansion.

A lot of systems come together to form a cohesive engine strong enough to power the development of a nation and the railway system should not be undermined in anyway especially in a progressive modern world like this. A modern transportation system is a necessity and prerequisite for socioeconomic growth and wealth creation towards good development as a nation. This is because changes in trade ties brought on by globalization entail changes in the logistics infrastructure of a country and its success on the international front. Dinye (2012) indicates that a significant population of countries rely on transport for their daily lives and survival, hence, the need for a quality, efficient and effective transport system.

\section{The Current Railway Development}

There are three lines (the Eastern, Western and Central line) in the current Rail network constructed during the colonial period and only about $13 \%$ of the roughly $947 \mathrm{~km}$ that operated in 1957 is still operating. The Ghana railway development agency revealed that with the new rail network proposed to be standard gauge, the current Ghana Railway Master plan under review with an investment of $\$ 21,507,902,000$ has prioritized phase two, three and five of the six phases aimed for completion of the $4007.6 \mathrm{~km}$ rail network (www.grda.gov.gh, 2018). According to (International Railway Journal, 2020), Ghana has ordered 35 standard gauge locomotives with coaches and freight wagons in addition for the operation of new lines. Its speed capacity reaches about $160 \mathrm{~km} / \mathrm{h}$ and has 15 freight locomotives and 11 hunters. This ongoing project started in 2018 and it keeps getting better and better. The rail infrastructure of Ghana has taken another turn as it is being reinvigorated comprising of modern narrow gauge rail lines as 
well as the construction of a number of replaced standard gauge lines. The Minister of Railways Development live on Eye on Port's interactive program on national television unveiled the procurement of more standard gauge stating clearly that "Standard gauge is what the African Union and ECOWAS have said that the entire Africa should use so that we can have train that will set off from Djibouti and come all the way to Ghana". He also made mention that "In East Africa, they are doing cross country railway line. We have started in Ghana that is the Ghana-Burkina rail line" (GHANAWEB, 2020).

This early startup of the railway project will cause a massive turn around regarding socio-economic development. For easy reach and faster transport many would love to live close to the rail routes and in turn create new communities and towns. Andoh (2018) says if it's well implemented, efficient railway networks will alter the way nations engage in their trading activities through the canons of conventional economic models and lift the speed at which they would develop. By engaging in numerous commercial events, this would allow people to increase their purchasing power. Based on the study of the modern transport system and Ghana's revised feasibility study for the expansion of existing railway infrastructures, there has been a New Railway network establishment which envisages the required infrastructure and services to meet the rising demand for mobility. In the Ghana Railway Development Authority (2014) report the new Railway Network will carry out the reconstruction and expansion of existing lines. An arrangement for the development of a standard gauge railroad line in the Ashanti locale has been endorsed by the Ghana Railways Development Authority (GRDA). Ghana Railway Technology (2020) also reports that under a $\$ 419 \mathrm{~m}$ contract awarded to India-based Afcons Infrastructure, the Tema-Mpakadan rail line has been in construction and a $51 \mathrm{~km}$ long standard gauge railway line from Eduadin to Obuasi will be built as well.

Figure 4 shows that a new station was built at Tema Community one including renovations at Achimota, Asoprochona, Baatsona and Odaw and there have been reconstructions and commissioning since the railway agenda begun and some are in use (www.grda.gov.gh, 2018). So far priority projects are almost

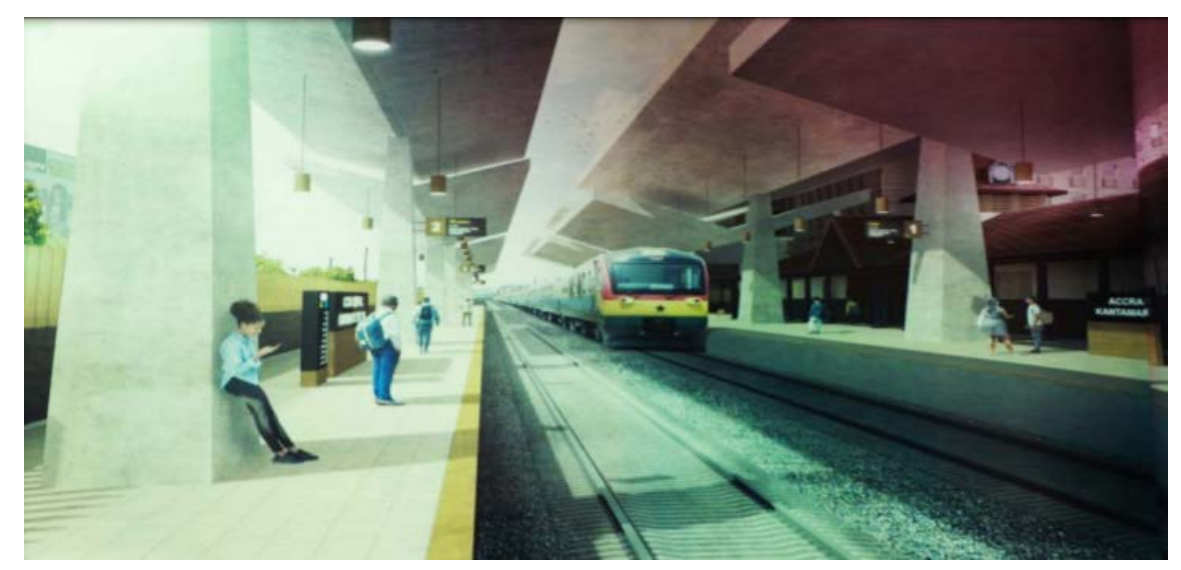

Figure 4. New railway station in Ghana. Source: Keddey (2018). 
completed. Progress on the New Standard Gauge Railway Line on The Western Line (2018) assures that the Accra-Tema railway rehabilitation is completed linking free zones and specially wired facilities to the seaport. The Takoradi-Tarkwa railway along the western line is also under development. Hammond (2020) echoed that railway rehabilitation will aid the mining and agricultural sectors in freight transport. The $40 \mathrm{~km}$ Achimota to Nsawam has been rehabilitated with a sub-urban commuter rail relaunch anticipation towards a corridor traffic ease.

\section{Review of the Rehabilitation Influencing Factors}

The remaining paragraphs provides an explanation of the influencing factors that affects the Ghanaian railway sector currently. The stance of the factors has been clearly illustrated below:

\subsection{The TRANS-ECOWAS Railway Line}

A feasibility study was undertaken in December 2018 towards the development of the railway project. The study was focused on economic, financial and environmental assessment of the proposed line, mapping-out the right-of-way and a business case strategy to attract investors. The Economic Community of West African States has an objective to link all member states by rail to boost trade and facilitate economic growth and development according to (Republic of Ghana Ministry of Railways Development, 2019).

Commencing at Aflao in the East, heading towards the West along the coast of the Gulf of Guinea, and finishing at the border with La Cote d'Ivoire, the total length of the proposed line is $530 \mathrm{~km}$. The Coastal Railway Network (CRN) Limited will undertake the construction on the basis of a Memorandum of Understanding signed with the Ministry of Railways Development. It will be a standard gauge line that will positively affect the socio-economic activities of towns along the corridors of the line (www.mrd.gov.gh, 2019). Transport reorganization and reclassification is expedient for the Trans-ECOWAS network to hold properly and in effect reduce food prices. Bayane Bouraima et al. (2020) agrees that sustained development is highly influenced by transport infrastructure and Sładkowski and Cieśla, (2015) presents intermodal transport as crucial with obvious benefits. Troch et al. (2015) acknowledges transport-GDP relationship as an economy booster. This shows how railway investment is a good opportunity with regards to intermodal linkage between countries and the environmental friendliness of rail-based intermodal freight movement.

\subsection{Carbon Emissions and Ghana GDP per Capita}

Organic matter is the result of the photosynthetic processing of Carbon dioxide $\left(\mathrm{CO}_{2}\right) \cdot \mathrm{CO}_{2}$ often emanate from use of the soil and other agricultural activities as by-product of fossil-fuel consumption and other industrial processes. The Earth's radiative equilibrium is influenced by the largest anthropogenic greenhouse gas. World Bank (2020) analysis shows that after the Industrial revolution, 
$\mathrm{CO}_{2}$ emissions, rate of global warming and ocean acidifications has shot up due to fossil fuel consumption, hence, environmental consequences of $\mathrm{CO}_{2}$ should not be overlooked. Gasses vary in the atmosphere and their balanced proportions is where the concern lies. $\mathrm{CO}_{2}$ accounts for less than a percentage of the greenhouse gasses. $\mathrm{CO}_{2}$ occurs naturally but its rise above its consistent proportions negatively impacts the environment. Deductions from (Stephen, 2018) says that High $\mathrm{CO}_{2}$ emissions has resulted in loss of shoreline and coastal wetlands, acidic precipitations affecting plant life and displacement of oxygen in the atmosphere jeopardizing human and animal life.

Research has shown that more investments in railway rehabilitation could substantially decrease $\mathrm{CO}_{2}$ emissions and its contributions towards air quality and positively reducing global energy demand. According to the International Energy Agency (IEA, 2019) Executive Director at the lunch of the Future Rail in New Delhi, "By diversifying energy sources and providing more efficient mobility, rail can lower transport energy use and reduce carbon dioxide and local pollutant emissions." Kim and Van Wee (2009) confirms reduction in emission of $\mathrm{CO}_{2}$ in rail-based intermodal freight systems generally.

As a country's GDP increases, its $\mathrm{CO}_{2}$ emission also increases because goods production and services increase. From $\mathrm{CO}_{2}$ Scorecard, Ghana's annual $\mathrm{CO}_{2}$ footprint is among the lowest in the world reducing by $-14.84 \%$ and improving $\mathrm{CO}_{2}$ intensity of the economy by $-30.05 \%$ as at 2011 . Over the last decade $\mathrm{CO}_{2}$ emissions has shot up to $73.98 \%$ proving increase in GDP (www.co2scorecard.org, n.d.a).

\subsection{Private-Public Investments}

Investments towards the Railway sector will certainly fast track the economic growth and development of Ghana. So far prioritized Railway phases have been well invested in by the Government of Ghana. Private sectors have showed a lot of interest in the Railway development and according to (Hammond, 2020), the Chief Executive Officer of GRDA stated that "additional financing sourced through build-own-operate-transfer agreements, barter agreements, and public-private partnership is integral to the success of the plan". Some minerals are mined as barter consistent with a railway line construction. Examples being the extraction of iron and bauxite for the same cost of rehabilitation.

Ghana Investment Promotion Centre (GIPC) clarified that "Urban rail on the continent is vital in providing a very efficient alternative to transporting large volumes of passengers and freight at high frequencies and reasonable cost. Rallying with this notion, Ghana has embarked on intense rehabilitation and development of its national rail network". The Ghana Rail development has a bigger agenda to support with respect to intra Africa trade. GIPC unveiled that the African Continental Free Trade Area (AFCFTA) would create an inexorable economic stability which will justify investments when implemented (www.ghanaweb.com, 2020).

For work efficiency and effectiveness towards railway coverage in light of the 
Master Plan, investments towards prioritized railway phases have been made to accomplish the development plan of construction and rehabilitation from the South to the North as seen in Table 2. Table 2 illustrates the investments cost incurred during the six phases of railway line development across the country. Using the Build Operate and Transfer (BOT) model, the Railway rehabilitation phases have mainly been financed through loans and the more popular Public Private Partnerships (International Trade Administration, 2020).

The initiation of these priority project will in turn build employment, promoting trade and industrial growth. According to the Ministry of Railways Development, "There are unlimited opportunities for the private sector in the development of the railway network, in the provision of related services and in the development of associated infrastructure. The Government of Ghana welcomes various forms of collaboration with the private sector in the development of the rail network, the provision of railway-related services and associated infrastructure in Ghana. Interested Investors towards the provision of the necessary resources for the rail construction and rehabilitation will in the long run boost Agricultural and mineral trade (www.mrd.gov.gh, n.d.a).

According to (Hayes, 2020), a Build-Operate-Transfer (BOT) contract is a model used to finance large projects, typically infrastructure projects developed

Table 2. The prioritized phases and investment costs.

\begin{tabular}{|c|c|c|}
\hline PHASE-LINES & DISTANCE & COST (USD) \\
\hline \multicolumn{3}{|l|}{ PHASE 2: Eastern “A” Expansion } \\
\hline Takoradi-Kumasi & 266.0 & $1,489,600,000.00$ \\
\hline Accra-Kumasi & 300.0 & $1,680,000,000.00$ \\
\hline Kumasi-Techiman-Tamale & 383.0 & $2,144,800,000.00$ \\
\hline \multirow[t]{2}{*}{ Tamale-Paga } & 212.0 & $1,187,200,000.00$ \\
\hline & 1161 & $6,501,600,000.00$ \\
\hline \multicolumn{3}{|l|}{ PHASE 3: (Sections) } \\
\hline Tamale-Yendi & 102.0 & $571,200,000.00$ \\
\hline Fufulsu-Sawla & 126.0 & $705,600,000.00$ \\
\hline Techiman-Atebubu-Kwadwokurom & 198.0 & $1,108,800,000.00$ \\
\hline \multirow[t]{2}{*}{ Nyinahin-Kumasi } & 58.0 & $324,800,000.00$ \\
\hline & 484 & $2,710,400,000.00$ \\
\hline \multicolumn{3}{|l|}{ PHASE 5: Western Expansion } \\
\hline Dunkwa-Awaso & 73.0 & $408,800,000.00$ \\
\hline Awaso-Techiman & 220.0 & $1,232,000,000.00$ \\
\hline Techiman-Sawla & 223.0 & $1,248,800,000.00$ \\
\hline \multirow[t]{2}{*}{ Sawla-Hamile } & 213.0 & $1,192,800,000.00$ \\
\hline & 729 & $4,082,400,000.00$ \\
\hline
\end{tabular}

Source: www.mrd.gov.gh, n.d.b. 
through Public-Private partnerships (PPP). BOT projects are normally largescale, Greenfield infrastructure projects that would otherwise be financed, built and operated solely by the government. Figure 5 below illustrates how the BuildOperate-Transfer Model is used in financing railway development in Ghana. Through PPP, the government and other private bodies come together to build a project, the private partners will operate the project for an agreed number of years and later transfer the operation power to the government to manage the affairs of the project and vice versa.

\subsection{Urban Sprawl Aversion}

In Tetteh (2021) submission, A crucial weapon used to combat urban sprawl has been the development of new towns with ample rail connections to major cities. Nechyba \& Walsh (2014) agrees that it smoothens supply chain and transport as well as food price reduction. GRDA has already completed five rail stations and commissioned them with semi-automatic barrier arm system. The successful completion of the priority project will increase employment and industrial growth as new towns come to being and road pressure is greatly reduced. Economic growth stimulation resulting from the priority project implementation will certainly constitute job creation, industrial development and trade boost. But more so develop new towns as well as cities and the rejuvenation of old towns.

Verbatim from (National Tourism Development Plan (2013-2027) Republic of Ghana, n.d.) "The existing system of tourism statistics has suffered from significant weaknesses for many years and this situation appears to have been brought about through a combination of institutional and financial shortcomings that have led to operational compromises, capacity constraints and the abandonment of a previous programme of statistics improvement." The extensively interconnected rail system will be a great influence, advantage and promoter of tourism in Ghana as it will provide possibilities for tourist movement nationally. Excursion railway routes will make it easier, faster and less expensive for tourists and as part of the envisioned projects the National Tourism Development Plan reveals the establishment of a Railway museum.

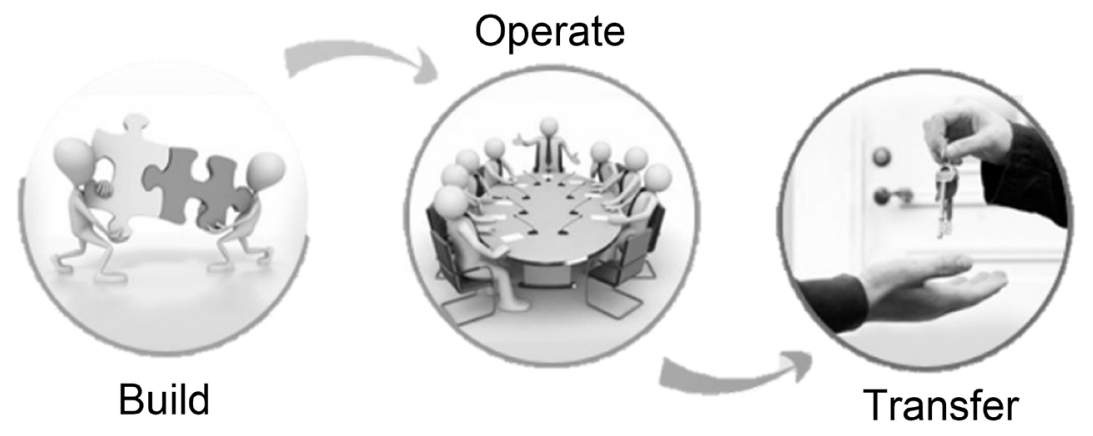

Figure 5. BOT model. Source: (penieldmin, n.d.). 


\subsection{The Rail Master Plan}

For both freight and passenger traffic, the narrow gauge and single-track lines were used for the three main lines (Western, Eastern and Central) and other branch lines. This in update is undergoing phase prioritized rehabilitation with standard gauge in the pipeline. The Western (Takoradi-Awaso-Kumasi) and Eastern (Accra-Tema-Kumasi) lines are undergoing a new technical standard adaptation. The Master Plan has six phases for the rehabilitation and extension of the rail network with three major priorities.

Prioritized phases (Master Plan Ghana, 2013)

Phase two-this phase covers approximately $1161 \mathrm{~km}$. it focuses on the track conversion to standard gauge and doubling the rehabilitated lines from the first phase.

Phase three-this phase covers approximately $484 \mathrm{~km}$ and focuses on transversal link extension with standard gauge single tracks.

Phase five - this phase covers approximately $729 \mathrm{~km}$ and focuses on extending the Western line to reach the future mines.

There's room made for the periodic revision and long-term monitoring interventions to update the master plan with unforeseen requirements. The new master plan with revised speed of $160 \mathrm{~km}$ per hour has 25 tons minimum axle load and the rail connects all regional capitals and economic lanes.

\subsection{Transportation and Costs}

Ghana has been depending on road transportation for a very long time with just little access to rail-link. Majority of its road network is found in Greater Accra, Western, Central and Ashanti region and the long-distance road system in the northern and central regions. Road transport has always been the dominating freight and passenger carrier amongst the rail, air and water networks system. Because of this there has been great pressure on the road transportation system; some being travel distance, accidents, armed robbery, transportation costs, over speeding, over loading and bad roads. The railway development implementation will highly subsidize and reduce this pressure since it largely contributes to socioeconomic development. Recent press release showed that transport fares were increased to accommodate the COVID-19 social distancing precautionary measures in public transport covering the intra-city, intercity and shared taxi transport system (www.mot.gov.gh, 2020).

\subsection{Mining sites}

The first Railway in Ghana was to serve the purpose of transporting minerals and heavy mining equipment for industrial use. According to Amponsah-Tawiah and Dartey-Baah (2011), the general macro-economic policy reforms has boosted mineral production with gold as the leading foreign exchange earner in Ghana as of 2005 attracting many investors. "Ghana is an important supplier of a variety of minerals to the world, hence, regarded as the African trailblazer ranking $3^{\text {rd }}$ 
among the geological ranking of African countries. Ghana is Africa's second most important producer of gold after South Africa, the third largest producer of manganese and aluminium and a significant producer of bauxite and diamonds" (Akabzaa, Darimani and Sapri, 2001). The manganese mines is serviced by the Western Division, Tarkwa (a gold mining center) to Prestea which is a branch line. Kojokrom is the junction of the line to Secondi with its other leg serving the port of Takoradi. Dunkwa to Awaso is another branch line on the Western Division that services bauxite mines. Achiasi to Kade is a branch line on the Central Division used to service timber companies and for cocoa transportation. Proper management of these natural resources will heavily contribute to sustainable development and poverty reduction, hence, the positive impact through safe and well-developed rail networks under the influence of recent mineral discoveries.

\subsection{Railway Training School}

MTEF for 2020-2023 MoRD PBB Estimates (2020) reveals that the Railway training school located at Essikadu has been well renovated to promote capacity building and skill development for the railway sector and very soon the training school will be transformed into an accredited tertiary institution. The railway sector will take another higher turn as this will build a solid core of Ghanaian Professionals in this area since it has come to stay. Practical and operational skills provided reflects railway school impact on the Railway Industry as a whole (Khalil, 2019). Figure 6 is an image of the school responsible for training railways staffs in Ghana with the exception of engineers responsible for other technical roles and hence have specialized training. Staffs not engaged in technical roles are trained in the Ghana railway training school.

\section{Current Rehabilitation Challenges}

\subsection{Slow Technology Embrace}

Ghana's development commenced with a vast ignorance in the aspect of railway architectural country development plan against a well-structured vehicle transport architecture. According to UNDP (2011), the knowledge-based development partnership offering high-quality counsel and reliable technical and economic

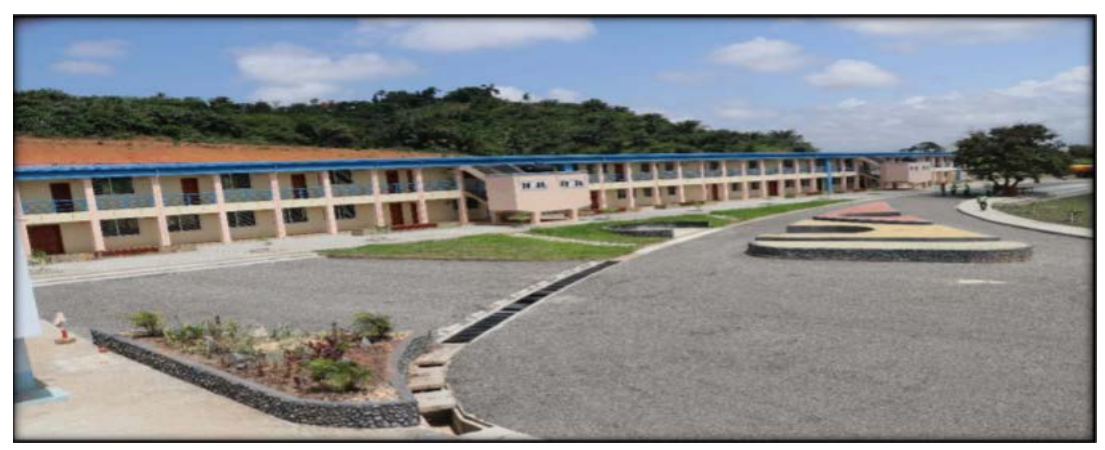

Figure 6. Ghana Railway Training school. Source: (MTEF for 2020-2023 MoRD PBB Estimates, 2020). 
expertise has been unreachable due to low level programme efficiency despite the (United Nations Development Programme) UNDP Ghana improvement efforts. The National development Planning Commission (NDPC) recognizes that the efficient use of resources towards rapid economic growth hinges on the Science and Technology integration in the various programme while maintaining environment integrity. The people's willingness to embrace modern technology is still on a slow rate especially in the rural developing areas and some urban centers as many hold on to ancestral buildings and lands. There have also been assertions that some construction lines are being sabotaged by road corridor haulers in defense of their business which the Minister of Railways Development addressed as an alternative business advantage for them.

\subsection{The COVID-19 Intrusion}

The projected Railway construction should have reached completion by August 2020 but was forced to standby since over 70 laborers tested positive for coronavirus. Even though the Government did what she could to exclude railways and roads from the lockdown to speed up the construction, the health of the laborers is a matter to consider. In the meeting at the Role of Rail in Multimodal Connectivity and Economic Growth in Ghana, The Minister said that "All our work across the railway sector have been affected by the COVID-19. Ghana Railway Company revenue has gone down, and they had to shut down their passenger services because they want to observe social distancing and they run at a massive loss". Even though there has been a slow down with regards to the Railway project, there has been some assurance to continue working on the project especially on the Tema-Mpakadan Railway. Much progress has been made since 97 $\mathrm{km}$ project begun. $65 \mathrm{~km}$ has been completed already since 2016 and the date predicted for final completion is March 2021 (Daily Guide, 2020). The railway master plan has in it the extension of the central spine rail lines to connect to the northern frontier and western lines for efficient use. Since the railway system and infrastructure has crumbled down before, it cannot afford to fail again after all the revival input. Therefore, ACEYE continues to build on expertise in favor of improved decision-making in relation to rail infrastructure growth in order to improve the progress of the Ghanaian Railway no matter the limitation (Africa Center for Entrepreneurship and Youth Empowerment, 2019).

\section{Conclusion (Possibility and Sustainability)}

The basic success metrics for project performance are time, quality and cost conventionally. The possibility and sustainability of these rehabilitations are but to ride on the objectives and influencing factors of the rail development. There have been private-public investments, the Master plan, budget and other contracts, the completed Railway training school, the procured rolling stocks, urban sprawl aversion projects, trans-ECOWAS connections, and planning and surveys and ongoing negotiation contracts that contribute to the efficacy of the de- 
velopment to promote socio-economic development and nation building. The performance achieved compared to the intended performance is by far a great progress. The relatively robust railway system was rolled out soon after the independence in 1957 connecting the coastal industrial cities to the resource and producing areas in the country stimulating economic activities of mining, timber and cocoa growing areas and also being the most preferred transport system among the businessmen and women in Ghana till its improper maintenance. But its current rehabilitation goes on with great speed and promises to impact Ghana greatly with a future-ready environment. A future-ready environ sets up basic foundations for future possibilities and the rail rehabilitation will not be overlooked. So many factors are considered to strategize sustainability especially in the railway sector, Human health, greenhouse gas emissions, construction impacts, renewable energy generations, climate threats, adaptation measures, and sustainable development policies and plans.

\section{Limitations and Future Research}

The study was faced with some inherent limitation during the investigation of the phenomenon. Since the rail rehabilitation only begun recently, secondary data on railway development in Ghana was quite difficult to access. However, researchers did a thorough and extensive review of literature in order to get information that permitted the report of the study. It is recommended to the ministry in charge of railway development to make sure information regarding railway development is made available on their websites and other forms so that future researchers can access them with ease to facilitate research to conduct more research on the current Ghanaian railway development and how influencing factors affect its effectiveness. For future research, researchers would like to extend the study to other neighbor countries in West Africa by comparing the effectiveness of railway development and its impact in their economic growth.

\section{Conflicts of Interest}

The authors declare no conflict of interest in publishing this paper.

\section{References}

Akabzaa, T., Darimani, A., \& Sapri, F. (2001). Impact of Mining Sector Investment in Ghana: A Study of the Tarkwa Mining Region. A Draft Report.

http://www.saprin.org/ghana/research/gha mining.pdf

Amponsah-Tawiah, K., \& Dartey-Baah, K. (2011). The Mining Industry in Ghana: A Blessing or a Curse.

https://www.researchgate.net/profile/Kwasi Dartey-Baah/publication/280557496 The Min ing Industry in Ghana A Blessing or a Curse/links/55b9045c08aed621de084c6c/The-M ining-Industry-in-Ghana-A-Blessing-or-a-Curse.pdf?origin=publication detail

Andoh, R. (2018). The Politics of Railway Transportation and Development in Ghana: A Case Study of Nsawam and Akim Achiase Junction Railway Stations. http://ugspace.ug.edu.gh/bitstream/handle/123456789/26116/The\%20Politics\%20of\%2 0Railway\%20Transportation\%20and\%20Development\%20in\%20Ghana\%2C\%20A\%20 
Case\%20Study\%20of\%20Nsawam\%20and\%20Akim\%20Achiase\%20Junction\%20Railw ay $\% 20$ Stations.pdf? sequence $=1$ \&isAllowed $=y$

Bayane Bouraima, M., Qiu, Y., Yusupov, B., \& Magloire Ndjegwes, C. (2020). A Study on the Development Strategy of the Railway Transportation System in the West African Economic and Monetary Union (WAEMU) Based on the SWOT/AHP Technique. Scientific African, 8, e00388. https://doi.org/10.1016/j.sciaf.2020.e00388

https://www.sciencedirect.com/science/article/pii/S2468227620301265

Daily Guide (2020). COVID-19 Cannot Stop the Completion of Tema-Mpakadan Rail Project-Contractor Assures. Modern Ghana.

https://www.modernghana.com/news/1021113/covid-19-cannot-stop-the-completionof-tema-mpakad.html

Dinye, R. D. (2012). Prospects and Issues of Railway Infrastructure and Development in Ghana. databank.worldbank.org.

https://journals.uj.ac.za/index.php/JCPMI/article/view/25/17

Dr. Tetteh, E. A. (2021). Revamping of the Railway Sector in Ghana-The Story So Far. https://www.myjoyonline.com/dr-evans-ago-tetteh-revamping-of-the-railway-sector-i n-ghana-the-story-so-far

Ghana Railway Development Authority (2013). Republic of Ghana, Ghana Railway Development Authority of the Ministry of Transport Provision of Engineering Consulting Services for the Preparation of the Railway Master Plan of Ghana Final Report Annex 1 Inception Report Abstract (Chapters 2-3-4-5-6).

https://new-ndpc-static1.s3.amazonaws.com/CACHES/PUBLICATIONS/2016/05/03/ Ghana+MP-+Final Annex+1-Inc.Report+Abstract.pdf

Ghana Railway Development Authority (2014). Study for Safety Operation and Management of Railway in Ghana. Final Report, Ghana Railway Development Authority, Republic of Ghana. https://openjicareport.jica.go.jp/pdf/12185674 01.pdf

GHANAWEB (2020). Ministry of Railways Development-Ghana-Railways Ministry to Order about 35 Trains.

http://www.mrd.gov.gh/4/16/108/railways-ministry-to-order-about-35-trains

Hammond, J. (2020). Engines of Growth: Ghana's Railway Boom. NewAfricaDaily, newafricadaily.com. https://newafricadaily.com/engines-growth-ghanas-railway-boom

Hayes, A. (2020). How Build-Operate-Transfer Contracts Work. Investopedia. https://www.investopedia.com/terms/b/botcontract.asp\#: :text=Key\%20Takeaways

IEA (2019). Railways Could Provide Much Greater Benefits for Energy and the Environment, According to IEA Report. News.

https://www.iea.org/news/railways-could-provide-much-greater-benefits-for-energy-a nd-the-environment-according-to-iea-report

International Railway Journal (2020). Ghana Orders New Standard Gauge Rail Equipment.

https://www.railjournal.com/africa/ghana-orders-new-standard-gauge-rail-equipment

International Trade Administration (2020). Ghana-Rail Industry. www.trade.gov. https://www.trade.gov/country-commercial-guides/ghana-rail-industry

Jedwab, R., \& Moradi, A. (2011a). Revolutionizing Transport: Modern Infrastructure, Agriculture and Development in Ghana Seminar.

http://eprints.lse.ac.uk/42263/1/Revolutionizing transport modern infrastructure $\% 2 \mathrm{C}$ agriculture and development in Ghana (LSERO).pdf

Jedwab, R., \& Moradi, A. (2011b). Transportation Infrastructure and Development in Ghana. https://halshs.archives-ouvertes.fr/halshs-00607207/document

Keddey, K. (2018). Vibrant Ghana Railway Sector in the Offing. Graphic Online. 
https://www.graphic.com.gh/features/opinion/vibrant-ghana-railway-sector-in-the-offi ng.html

Khalil, A. A. (2019). Major Impacts of Learning Outcomes of Railway Engineering on the Operation Performance Indicators of the Egyptian Railways. https://www.researchgate.net/publication/330535526

Kim, N. S., \& Van Wee, B. (2009). Assessment of $\mathrm{CO}_{2}$ Emissions for Truck-Only and RailBased Intermodal Freight Systems in Europe. Transportation Planning and Technology, 32, 313-333. https://doi.org/10.1080/03081060903119584

Master Plan Ghana (2013). https://new-ndpc-static1.s3.amazonaws.com/CACHES/PUBLICATIONS/2016/05/03/1 -MASTER+PLAN+GHANA+FINAL+REPORT+-+Fin4.pdf

MTEF for 2020-2023 MoRD PBB Estimates (2020). https://www.mofep.gov.gh/sites/default/files/pbb-estimates/2020/2020-PBB-MoRD.pdf

National Tourism Development Plan (2013-2027) Republic of Ghana (n.d.). https://www.ghana.travel/wp-content/uploads/2016/11/Ghana-Tourism-DevelopmentPlan.pdf

Nechyba, T., \& Walsh, R. (2014). Urban Sprawl. Journal of Economic Perspectives, 18, 177-200. https://www.researchgate.net/publication/4746160 Urban Sprawl

penieldmin (n.d.). BOT (Build, Operate and Transfer). Peniel Doxa Consulting. https://www.penieldoxaconsulting.com/advisory-services/bot-build-operate-and-transfer

Progress on the New Standard Gauge Railway Line on the Western Line (2018). Progress on the New Standard Gauge Railway Line on the Western Line. YouTube. https://youtu.be/7csUckvQvNU

Railway Technology (2020). Ghana's GRDA Signs Deal to Develop Rail Line in Ashanti Region. http://www.railway-technology.com https://www.railway-technology.com/news/ghana-grda-rail-line-in-ashanti-region

Republic of Ghana, Ministry of Railways Development (2019). 2018 Annual Report. https://s3-us-west-2.amazonaws.com/new-ndpc-static1/CACHES/PUBLICATIONS/20 20/02/10/Ministry+of+Railways+Development 2018+APR.pdf

Sładkowski, A., \& Cieśla, M. (2015). Influence of a Potential Railway Line Connecting the Caspian Sea with the Black Sea on the Development of Eurasian Trade. Naše More: Znanstveni časopis za more i pomorstvo, 62, 264-271.

https://doi.org/10.17818/NM/2015/4.4

https://hrcak.srce.hr/index.php?show=clanak\&id clanak jezik=220698

Stephen, M. (2018). The Effects of Human Intervention on the Environment. Sciencing. https://sciencing.com/effects-human-intervention-environment-23067.html

Troch, F., Vanelslander, T., Léonard, A., Limbourg, S., Merchan, A., Mostert, M., Pauwels, T., Stevens, V., Sys, C., Tawfik, C., \& Verhoest, K. (2015). BRAIN TRAINS: Intermodal Rail Freight Transport and Hinterland Connections: A SWOT Analysis to Assess the Belgian Rail Practice.

https://orbi.uliege.be/bitstream/2268/184376/1/PAPER\%20BIVEC\%202015.pdf

UNDP (2011). Assessment of Development Results Evaluation of UNDP Ghana. https://www.oecd.org/countries/ghana/47860855.pdf

World Bank Group (2020). Ghana. Data. Worldbank.org. https://data.worldbank.org/country/ghana

www.co2scorecard.org (n.d.). $\mathrm{CO}_{2}$ Scorecard. Country Data. Dashboard. https://www.co2scorecard.org/countrydata/Index/4188

www.gfzb.gov.gh (2020). Country Profile-Ghana Free Zones Authority. 
https://gfzb.gov.gh/index.php/country-profile/

www.ghanaweb.com (2020). GIPC Boss Calls for Financial Investment in Railway Sector. https://www.ghanaweb.com/GhanaHomePage/business/GIPC-boss-calls-for-financialinvestment-in-railway-sector-1014253

www.grda.gov.gh (2018). Ghana Railway Development Authority—GRDA.

http://www.grda.gov.gh

www.mot.gov.gh (2020). Press Release Arbitrarily Increase in Transport Fares. Ministry of Transport, Ghana.

http://www.mot.gov.gh/10/16/71/press-release-arbitrarily-increase-in-transport-fares

www.mrd.gov.gh (2019). Government Committed to the Development of the Trans ECOWAS Railway Line. Ministry of Railways Development, Ghana.

http://www.mrd.gov.gh/4/16/102/government-committed-to-the-development-of-the-t rans-ecowas-railway-line

www.mrd.gov.gh (n.d.a). Priority Projects. Ministry of Railways Development, Ghana. http://www.mrd.gov.gh/3/2/priority-projects

www.mrd.gov.gh (n.d.b). Data Table. Ministry of Railways Development, Ghana. http://www.mrd.gov.gh/7/14/data-table 